\title{
EVALUATING THE ENGLISH TEXTBOOK FOR YOUNG LEARNERS
}

\author{
Hertiki \\ Universitas PGRI Adi Buana Surabaya \\ hertiki@unipasby.ac.id
}

\begin{abstract}
Evaluating the English textbook used at one of the National Plus Schools in Surabaya (SNA), this study aims at finding out whether "My Pals are Here!" fulfill the objectives of teaching English and whether it is designed according to the principles of Teaching English to Young Learners (TEYL). Further, the instrument of this study was the researcher herself and equipped with an Evaluation Checklist by Bilash (2009). Also, an interview with a teacher who has used that book in class provided for this research. Using the checklist, it was found out that "My Pals are Here!" is in accordance with the objective of teaching English at SNA, which is to help learners to be able to use English for communication especially orally. "My Pals are Here!"' is also fulfill the principles of TEYL.
\end{abstract}

Keywords: English textbook, textbook, young learners

\section{INTRODUCTION}

In Surabaya, there are many preschools and elementary schools with the label of International School or National Plus Schools. Those schools use different kinds of the curriculum such as Cambridge, Montessori, International Baccalaureate (IB), and International Primary School Examination (IPSLE). Besides, those schools also use English textbooks and English as a medium of instruction in class. There is a tendency, those schools tried to get more students with International Curriculum. The teachers in the school are foreigners, for example, Filipinos, Singaporean, American, and British.

These teachers are forced to follow a particular book decided by the school's curriculum. The teachers do not have the chance to choose the book which is appropriate with the school curriculum as well as for the students. However, as has been mentioned by the writer, the teachers still do not know how to evaluate a textbook. Thus, principals, teachers, and the coordinator of courses must have the ability in choosing the most suitable English textbook for the students. If they are unable to choose the right textbook for students, then the English teaching-learning process will be failed.

One of the National Plus Schools in Surabaya called SNA has been using an English textbook named My Pals are Here!. This book has different series from Primary 1 (P1) to Primary 6 (P6). It has been observed that the teacher often tries to find supplementary materials from other sources, for instance: the internet. Therefore, the book of My Pals are Here! was evaluated in two aspects: (1) whether My Pals are Here! is in accordance to the objectives of teaching English 
at SNA; (2) whether My Pals are Here! is designed according to the principles of TEYL.

\section{The Principles of Teaching English to Young Learners}

One of the experts in the field of teaching English to young learners, McCloskey (2002) mentioned that there are seven principles related to TEYL:

1. Providing young learners with different kinds of activities so that they can learn best when they enjoy the activities;

2. Helping young learners practice and develop language through collaboration;

3. Integrating the four skills with content;

4. Providing clear aims and feedback on student's performances;

5. Using well-prepared activities;

6. Providing intelligible input with scaffolding; and

7. Validating and integrating home language and culture.

Halliwell (1995) also stated about children's characteristics. First, young learners are creative in using their limited language resources. Second, they are also good at clarifying meaning without necessarily understanding the individual words. The third characteristic of children is they like interesting real tasks. Fourth, children also use their imagination and fantasy when playing together or even alone. The last characteristic is, by nature, children like talking and very active.

All of these characteristics are fruitful for language learning. Thus, teachers must be wise and creative in helping young learners in learning English. The characteristics of young learners and teaching principles must be taken into considerations when choosing a course book for young learners.

\section{The Use of Textbook in Primary Education}

It is necessary to emphasize that there is no ideal textbook for teachers and learners and ideal in every teaching situation. Furthermore, many teachers are required to use textbooks in a classroom. On the other hand, in some schools, there are some teachers reject the textbook approach for learning and wish to make changes to the textbook they need to use. Before using the textbooks, teachers also are supposed to join the training in modifying textbooks. For the students, the textbook is one of the most important sources they have with the language. It guides and helps them to organize their learning. It is also helpful to involve students in the process of adapting textbooks.

Graves (2000:175) defined that the textbook is a book used as a standard source of information for formal study of a subject and an instrument for teaching and learning. The use of textbooks in teaching has both advantages and disadvantages. These are the following advantages of using textbooks:

a. It provides a set of classroom activities and helps the teacher in finding or developing materials.

b. It provides with evaluation tools for assessing students' learning.

c. It provides a course syllabus about what will be learnt.

d. It may include supporting materials such as: CD, video, worsheets and teacher's guide.

e. It provides a road map of the course. 
However, textbooks also have limitations, which can lead to teachers' and students are not satisfied with the lesson. These are disadvantages of using textbooks:

a. The content may not be at the right level for the students.

b. The examples may not be appropriate to the group and they may not reflect the students' needs since textbooks are often written for global markets and often do not reflect the interests and needs of students

\section{Evaluation of an English Textbook}

An English textbook must be evaluated since not every textbook is appropriate to use for teaching. O'Neill (1982) stated that textbook represent the visible heart of any English program of the language input learners that they receive in the classroom. A good teacher can evaluate the textbook by identifying the strengths and weaknesses based on the objective of teaching. As Pinter (2006) mentions, one obvious purpose of an evaluation can be used to identify in which the available textbook can be supplemented or to propose a better textbook by replacing the old one with the new one. In addition, as Richards (2001) suggested that textbooks may provide the basis content of the lessons, and language practice for the students to take part in. In other situations, textbooks may also supplement the teacher's instruction in a classroom.

In selecting the materials suitable for young learners, teachers must prepare the children with fully formal language teaching (Brewster, 2007). Besides, teachers also focus on evaluation and select a suitable textbook for young learners. According to Dickinson (2010), the evaluation can be done by using an evaluation checklist, covering these following areas: Design and Layout, General Appearance, Language Skills, Language Content, Activities, Methodology, Topic Content, and Assessment. That's why it is very beneficial to review Blush's theory (2009) about criteria for a communicative activity in evaluating the activities in the textbooks whether to meet the criteria or not. She also mentioned that the activity must be interesting in order to motivate young learners in completing the target language.

\section{SNA Profile}

SNA is a National Plus School for children and teenagers managed by Maspion Group with the Singapore curriculum, located in Sidoarjo, East Java, Indonesia. SNA uses a Singapore-based curriculum. The students mainly speak English as its first medium instruction, however, they still have chances to speak Chinese and Indonesian language during Chinese and Indonesian classes.

SNA helps young learners to learn English and to be able to use English for daily communication. Since 2010, SNA implemented Singapore Primary School Curriculum based on the Singapore Ministry of Education. In completing the primary education, the students sit for the Singapore International Primary School Leaving Examination (IPSLE). There are six levels in SNA, from Primary 1 to Primary 6. The data shows that SNA has 180 students spreading in 12 classes with 3 instructors for teaching English. For the sake of the young learners' intensive learning, each class consists of maximally 15 pupils. The scheduling system applied is a twice-a-week for English subject in the morning, each in 60 minutes. 


\section{METHOD}

This study is a descriptive study. The survey form is used to describe a textbook, interview, and questionnaire. The subject of the study is an English textbook for young learners, My Pals are Here!. The book consists of a workbook and a teacher's book. This book is from foreign publishers.

The instrument of this study is the researcher herself. According to Bilash (2009), criteria for a communicative activity is used to evaluate the activities in the textbook. An interview with the teachers is also used in order to gain valid data. These are the questions of the interview:

1. Do the activities in My Pals are Here encourage the students to be active in the classroom?

2. In what aspects do My Pals are Here need to be supplemented?

3. Does the methodology in My Pals are Here help the young learners to be active in the classroom?

4. Are the vocabularies in the book suitable for the students' level?

5. Do the activities help the students to speak more using English in class?

The evaluation check list is done by the researcher based on the Bilash's criteria checklist. In addition, for the triangulation of the data, the teacher who has used the textbook was also asked to fill in the Evaluation Checklist. The criteria includes general appearance, layout and design, methodology, activities, language skills, language content, topic content, teachability and flexibility, assessment, and practical considerations. The following criteria can be seen below, adapted from Dickinson, Pinter, and Brewster (2007):

\section{General Appearance}

a. The book cover is attractive to young learners

b. The font size and type are appropriate for young learners

c. The book contents and workbook materials look fun and interesting to young learners

2. Layout and Design

a. The book includes a detailed overview of the structures and vocabulary that will be taught in each unit

b. The layout and design is clear

c. The textbook is clearly structured

d. The learners can easily see what they have to do

e. The illustrations are varied and attractive

f. The illustrations stimulate learners to be creative

3. Methodology

a. The suggested methodology is learner-centered

b. The suggested methodology in presenting new language items are suitable for young learners

c. The materials can be easily adapted to suit various approaches

\section{Activities}

a. There are sufficient activities and tasks which are interesting in themselves and not just for language production activities

b. There are plenty of activities for children who cannot yet read and write with confidence

c. There are plenty of varied practice for any one set of language items /skill 
d. The activities provide opportunities for real languge use and possibilities for language interaction

e. The activities incorporate individual, pair and group work

f. The activities promote creative, original and independent responses

g. The activities are conducive to the internalization of newly introduced language

h. The activities can be modified or supplemented easily

\section{Language Skills}

a. The materials provide an appropriate balance of the four language skills

b. There is sufficient material for integrated skills work

c. Listening material is well recorded, as authentic as possible, and attracts the interest of young learners

d. There is sufficient range of interesting, level-appropriate reading material

\section{Language Content}

a. The language used in the book is sufficiently authentic

b. The language used is at the right level for my students' current English ability

c. The language functions exemplify English that students will be interested in and likely to use

\section{Topic Content}

a. The topics are realistic and likely to appeal to young learners

b. The topics are relevant and encourage learners to express themselves

c. The topics encourage independent thinking and active learning

d. The book avoids cultural/racial/sexual stereotypes

e. The topic reveals clearly what students are expected to learn in that unit

\section{Teachability and Flexibility}

a. The book provides sufficient support, such as CDs, cassettes, DVD, flashcards, posters to help students get a clear input

b. The book is suitable for mixed ability classes and classes of different sizes

c. The teacher still has to supplement the coursebook with materials from other sources

\section{Assessment}

a. The book provides adequate opportunities for learner assessment

b. Adequate assessment materials such as progress tests are included or easily obtained

\section{Practical considerations}

a. The book is affordable for the parents to buy

b. The book is available in the bookstores

Also, the teacher was interviewed to get supporting data. The researcher evaluated the book by using the Bilash' criteria checklist and the Evaluation sheet. The data was analyzed and interpreted by using Bilash' and Evaluation checklist. The result of the interview was transcribed to get more supportive data.

\section{FINDINGS}

The objective of teaching English at SNA is to help young learners to be able to use English for communication. Thus, the criteria of this study were used 
to evaluate the textbook in accordance with the objective of teaching English at SNA since mostly activities in the textbook meet the criteria of a communicative activity (Bilash, 2009). Most of the activities used authentic materials and involved the interactions of the students in the classroom. Meanwhile, the instructions are given in the target language and that is in English. In the efforts of finding out whether My Pals are Here is designed according to principles of TEYL, based on an Evaluation Checklist adapted from Brewster's, Dickinson's, and Pinter's.

\begin{tabular}{|c|c|}
\hline ASPECTS/BOOK & My Pals are Here \\
\hline $\begin{array}{l}\text { General } \\
\text { Appearance }\end{array}$ & Cover and content are suitable for the children. \\
\hline Layout and Design & $\begin{array}{l}\text { The layout and design are full-colored and appropriate for the } \\
\text { children. The textbook is designed clearly structured and it } \\
\text { has eight units. Each unit consists of Listening, Speaking, } \\
\text { Reading, Writing, Vocabulary, and Grammar. }\end{array}$ \\
\hline Methodology & $\begin{array}{l}\text { It is student-centered because it focuses on how young } \\
\text { learners get involved in every task and also how they express } \\
\text { their opinions in a creative way. }\end{array}$ \\
\hline Activities & $\begin{array}{l}\text { Different kinds of activities for each language skill provide } \\
\text { chances for young learners to be active in the classroom. The } \\
\text { language interaction in the classroom can be individual, pair, } \\
\text { and group-work. Each unit has different activities, but still } \\
\text { focus on the four skills and also vocabulary and grammar as } \\
\text { well. }\end{array}$ \\
\hline Language Skills & $\begin{array}{l}\text { The textbook covers all the four skills and added with } \\
\text { vocabulary and grammar activities. }\end{array}$ \\
\hline Topic Content & $\begin{array}{l}\text { The topics are designed with themes from the pupils' world } \\
\text { of school, family, and friends. The following topics content } \\
\text { are: } \\
\text { 1. Going to School } \\
\text { 2. My Family and Friends } \\
\text { 3. Colors, Shapes, and Sizes } \\
\text { 4. Caring and Sharing } \\
\text { 5. Where I Live } \\
\text { 6. Jobs People Do } \\
\text { 7. On the Farm } \\
\text { 8. What is in the Garden? }\end{array}$ \\
\hline $\begin{array}{l}\text { Practical } \\
\text { Considerations }\end{array}$ & $\begin{array}{l}\text { The book is made of with strong cover fine printing and high- } \\
\text { quality paper. Also, the parents can afford the book in the } \\
\text { bookstore at school though the price is quite expensive. } \\
\text { However, the book is available at book distributors only. The } \\
\text { book has a thick cover and paper. }\end{array}$ \\
\hline Teachability & The book provides with audio CDs and workbook. The \\
\hline
\end{tabular}




\begin{tabular}{|c|c|}
\hline Flexibility & $\begin{array}{l}\text { workbook is provided with various additional exercises such } \\
\text { as: } \\
\text { 1. Matching the words with the pictures } \\
\text { 2. Finding the words } \\
\text { 3. Finishing the crossword puzzle } \\
\text { 4. Filling in the blanks with the correct words } \\
\text { 5. Unscrambling the letters } \\
\text { 6. Coloring the pictures } \\
\text { 7. Rewriting the sentences using a capital letter and a full } \\
\text { stop } \\
\text { 8. Reading the short passage } \\
\text { The exercises reinforce lessons from the textbook and extend } \\
\text { the pupil's learning. They are graded in terms of difficulty } \\
\text { and become increasingly challenging as the units progress. } \\
\text { The exercises are also challenging and requiring pupils to } \\
\text { think critically. }\end{array}$ \\
\hline Language Content & $\begin{array}{l}\text { The language conventions taught in the textbook are } \\
\text { reinforced in the workbook in the form of notes such as: } \\
\text { - Names begin with capital letters. } \\
\text { - Remember to use a before words that begin with a, e, i, } \\
\text { o, and u vowel sounds. } \\
\text { - Remember that a sentence begins with a capital letter } \\
\text { and ends with a full stop. } \\
\text { The language is also authentic because it can be used for daily } \\
\text { communication outside the classroom. }\end{array}$ \\
\hline Assessment & $\begin{array}{l}\text { The textbook provides well-to-do opportunities for the } \\
\text { learners in the form of reviews for each unit. The book of My } \\
\text { Pals are Here also contains the workbook including exercises } \\
\text { and an audio CD. Here, the function of the assessment is as a } \\
\text { tool to check pupils' understanding. }\end{array}$ \\
\hline
\end{tabular}

Table 1: Evaluation Checklist

\section{Teacher's Books}

The learning of English should be a fun and rewarding experience for the students. Through the My Pals are Here, the students learn the English language in a most enjoyable and enriching way. Pupils are given many opportunities to speak, read, and write in English. Learning becomes integrated as grammar, vocabulary and other skills for language use. They are also introduced to a wide variety of text types, such as: poems, letters, and instructions. The colorful illustrations are also designed to stimulate pupils' interest and imagination. The book of grade 1 is also provided with teacher's book. These are the following content of the teacher's book:

a. Summary of contents and unit overviews to aid planning

b. Detailed lesson plans including lesson objectives, answer keys and instructions make lesson planning and teaching simple 
c. Ideas and tips for warm-up activities, optional extension activities, and differentiated instructions help teachers enhance lessons

d. Listening scripts and an Audio CD for the students' book and workbook provide pupils and teachers with a comprehensive learning package

\section{Grammar Activities}

In "My Pals are Here!", grammar rules and language conventions are made explicit in the notes. Also, there are many grammar exercises, the grammar items are well sequenced and the difficult patterns are extensively explained in the teacher's book. For example Grammar Language for Interaction. The teaching point is to encourage pupils to role-play helping out at home. They should ask questions in the form of "Can I....?" or "May I ....?" and answer, "Yes, you can." or "Yes, you may."

\section{How does everybody help out in the family?}

Mother cooks dinner.

A: May I help you, Mum?

B: Yes, you may.

Grandmother waters the plants.

A: Can I help you, Grandma?

B: Yes, you can.

Father washes the dishes

A: Can I help you, Dad?

B: Yes, you can

Grandfather sets the table

A: May I help you, Grandpa?

B: Yes, you may.

Table 2: Grammar Language for Interaction

\section{DISCUSSION}

From the findings above, it can be concluded that "My Pals are Here!" is suitable for young learners in several aspects, such as General Appearance, Layout and Design, Activities and Language skills. Lopez and Mendez (2005) mentioned that the criteria of a good textbook must be equipped with a cover containing the title, level, and author. Besides, the layout uses basic colors like green, yellow, blue, red, and not to use darker colors such as grey, purple and brown. Also, the pages are made of thick paper and contain colorful pictures. The font type of Comic Sans and size 18 are appropriate for young learners. The activities and language skills of "My Pals are Here!" are in accordance with the characteristics of young learners (Halliwell, 1995). The activities gave help the students to be more creative and also they are challenged to do the tasks in a class. In addition, the language skills focus on the four-skills that is starting from Listening, Speaking, Reading and Writing. The book is also supported by 
Grammar and Vocabulary. The students do not see the difficulty in doing the work because it has simple instructions.

According to Gower (2005), the book of "My Pals are Here!" contains a well-balanced language work (Grammar and Vocabulary) and skills (Listening, Speaking, Reading and Writing). The teacher's book is helpful in giving guideline how to use materials and it states aims and the objectives as well. Related to the methodology, Paul (2003) mentioned that children need to participate in every stage of the learning-teaching process in class. The activities in "My Pals are Here!" require students to do their work individually, in pairs, in groups interaction in oral and written. The activities are formed from easy to difficult, presented with different topics that are familiar with the students. The listening materials are also supported in the form of a CD.

\section{CONCLUSION}

From the findings above, it can be concluded that "My Pals are Here!" are in accordance to the objective of teaching English at SNA, which aims to help the young learners to be able to use English for communication. The textbook is designed based on the principles of Teaching English to Young Learners. The book has an additional plus point especially in the aspects of language content, topic content, grammar and teacher's book.

SNA school consider "My Pals are Here!" as an important resource in the English lesson and is also available in the library. To speak more broadly, the researcher would like to give a suggestion for other teachers to be more careful in selecting a textbook. In choosing a good textbook for young learners, the teacher must consider layout, design and general appearance.

The qualifications above do not always guarantee that the content is like what is expected. Therefore, it is important to take time studying the content and other aspects of a book before deciding to use it. Besides, it is also beneficial to have a discussion with other teacherss to compare some potential books by finding out the strengths and weaknesses of each. Finally, for further research, considering that there are some kinds of textbooks for young learners, it is recommended that other researchers should make studies in evaluating other foreign published books to contribute useful information to those who are involved in teaching English to young learners.

\section{REFERENCES}

Bilash, O. (2009). Communicative Activities. Retrieved from http://www.educ.ualberta.ca/staff/olenka.bilash on July 25, 2013.

Brewster, J. et al. (2007). The Primary English Teacher's Guide. Harlow: Pearson Education Limited.

Dickinson, P. (2010). Evaluating and Adapting Materials for Young Learners. Birmingham: Centre for English Language Studies, Postgraduate Programmes, University of Birmingham.

Gower, R., Phillips, D., Walters, S. (2005). Teaching Practice Handbook. Oxford: Macmillan.

Graves, K. (2000). Designing Language Course, A Guide for Teachers. Boston. Heinle. Cengage Learning. 
Halliwell, S. (1995). Teaching English in the Primary Classroom. New York: Longman Publishing.

Kirkgoz, Y. (2009). Evaluating the English Teaxtbooks for Young Learners of English at Turkish Primary Education. Accessed from http://www.sciencedirect.com on February 9, 2019.

Ling, J. \& Smith, A. (2006). My Pals are Here. Marshall Cavendish Education: Singapore.

McCloskey, M. L. (2002). Principles for Teaching Young Learners of English. (Online),http://home.comcast.net/ mariluwho/Handouts05/Multiplyer1005. pdf. Retrieved on February 10, 2011.

Mendez, R.V., Lopez, B.R. (2005). Assessing Young Learners' English Materials. Porta linguarum 3, enero 2005. pp. 59-77. Retrieved from http://www.ugr.es/ portalin/articulos/PL on February 15, 2010.

O’Neill, R. (1982). Why Use Textbook?. ELT Journal, 36 (2), 104-111.

Paul, D. (2003). Teaching English to Children in Asia. Hong Kong: Longman Asia ELT.

Pinter, A. (2006). Teaching Young Language Learners. Oxford: Oxford University Press.

Richards, J. C. (2001). The Role of Textbooks in a Language Program. Retrieved from http://www.professorjackrichards.com/pdfs/role-of-textbooks.pdf on November 12, 2008. 